Piśmiennictwo zakonne $w$ dobie staropolskiej, red. Magdalena Kuran, Katarzyna KaczorScheitler i Michał Kuran, przy współpracy Dawida Szymczaka, Łódź 2013.

Anna Reglińska-Jemiot ${ }^{1}$

Uniwersytet Gdański

\title{
Myśl teoretyczna o sztuce tańca w piśmiennictwie jezuickim XVII i XVIII wieku
}

Swój program edukacji artystycznej jezuici zawsze przystosowywali do miejscowych tradycji — stąd różnorodność i narodowy charakter sztuki tego zakonu. Członkowie Towarzystwa Jezusowego dostrzegali ambicje i oczekiwania społeczności, wśród których pracowali. Chociaż to właśnie stawało się również przyczyną ich krytyki. Jan Brożek stwierdzał złośliwie, że jezuici „habit inszy mają w Chinie, inszy w Japonach, inszy w Anglie, inszy między Grekami”2.

Nie znajdziemy na temat edukacji tanecznej żadnych pedagogicznych zaleceń w oficjalnym programie wychowawczym Societatis Iesu. Podobnie Ratio studiorum nie zawiera nic na temat lekcji tańca i występów tanecznych. Taniec pojawił się w codziennej edukacji pod wpływem oddziaływania specyficznych bodźców kulturowych ${ }^{3}$. Zasługą jezuitów niewątpliwie w tej kwestii była zdolność adaptacji i rozpoznawanie tych kluczowych tendencji w europejskiej kulturze i rozwoju społecznym. W bezpośredniej praktyce szkolnej udało się członkom zakonu wypełniać powierzone im zadanie edukacji szlachty przy pomocy najbardziej aktualnych i efektownych środków przekazu (zarówno w dziedzinie literatury i religii, jak i nauki etykiety, kształtowania dworskich manier).

\footnotetext{
${ }^{1}$ Dr Anna Reglińska-Jemioł, pracownik Katedry Historii Literatury Uniwersytetu Gdańskiego. W 2008 roku obroniła rozprawę doktorską o Formach tanecznych w polskim teatrze jezuickim XVIII wieku. Jej badania naukowe skupione są wokół zagadnień kultury tanecznej epok dawnych — ze szczególnym uwzględnieniem teorii i praktyki sztuki baletowej epoki oświecenia; świadectw odbioru tych przedstawień; a także pojęcia libretta baletowego jako tekstu. Działalność w towarzystwach naukowych: Polskie Towarzystw Badań nad Wiekiem Osiemnastym; Polskie Towarzystwo Historyków Teatru; Komisja Historii Nauk Społecznych Komitetu Historii Nauki i Techniki Polskiej Akademii Nauk; Société Internationale d' Histoire Comparée du Théâtre, de l'Opéra et du Ballet oraz International Federation for Theatre Research. Ważniejsze publikacje z ostatnich lat: P. Kąkol, A. Reglińska-Jemioł, Chinoiserie w sztukach widowiskowych w Polsce XVIII wieku, [w:] Poczatki wiedzy o Chinach w Polsce, red. I. Kadulska i J. Włodarski, Gdańsk 2008; A. Reglińska-Jemioł, Prowincja tańczy. O edukacji tanecznej w prowincjonalnych szkotach w XVIII wieku, [w:] Między barokiem a oświeceniem, red. S. Achremczyk, Olsztyn 2008, „Rozprawy i Materiały Ośrodka Badań Naukowych im. Wojciecha Kętrzyńskiego w Olsztynie”, nr 231.

${ }^{2}$ J. Brożek, Wybór pism, t. 1, oprac. H. Barycz, Warszawa 1956, s. 303.

${ }^{3}$ Zespół obowiązujących zasad związanych z próbami wprowadzania nauki tańca w placówkach jezuickich przybliża w swej pracy Jan Poplatek (Studia $z$ dziejów jezuickiego teatru szkolnego $w$ Polsce, Wrocław 1957).
} 
Nadrzędną rolę pełniło oczywiście wychowanie religijne i moralne, ale stawiano również na harmonijny rozwój jednostki - obok wykształcenia formalnego gwarantowano rozwój fizyczny młodzieży ${ }^{4}$, dostrzegając potrzebę ruchu, rozrywki i zabawy. I tak właśnie w ramach rekreacji wprowadzano obok jazdy konnej i szermierki — taniec 5 .

Spod pióra członka Towarzystwa Jezusowego - Claude’a Françoisa Ménestriera wyszło pierwsze historyczne opracowanie dziejów tańca (Des ballets ancien et modernes selon les règles du théâtre). C.F. Ménestriera możemy nazwać nie tylko pierwszym historykiem tańca, ale także jednym z bardziej wpływowych krytyków sztuki baletowej XVII wieku. W kolejnych stuleciach autorzy encyklopedii, słowników i leksykonów wiedzy o tańcu swe definicje związane z tańcem tworzyli w dużej mierze w oparciu o odkrycia Ménestriera ${ }^{6}$.

Wydanie Des Ballets anciens et modernes w 1682 roku było wielkim wydarzeniem kulturalnym. Wielu współczesnych teoretyków i historyków tańca zgodnie podkreśla, że był to moment przełomowy w dalszym rozwoju myśli estetycznej o tańcu, stawiany na równi z tak niezwykłym wydarzeniem, jakim było pojawienie się na scenie teatralnej kobiet. Wielu badaczy zwraca też uwagę na fakt, że rozważania swe Ménestrier jako pierwszy ujmuje całościowo — nie pomijając kompozycji, stylu wykonania, akcji odpowiedniej dla baletu, dekoracji i muzyki. Niemal jednogłośnie stwierdza się, że Des Ballets ancien et modernes stanowi dzieło kompletne o historii sztuki tanecznej.

Autor poddał tu analizie blisko pięćdziesiąt francuskich i włoskich spektakli baletowych. Dostarczył badaczom wykazu 48 tytułów ważniejszych spektakli baletowych z czasów Ludwika XIII i Ludwika XIV. Nie zabrakło tu też wskazówek praktycznych odnośnie reżyserowania form baletowych (rozdz. La conduite du Ballet), użycia konkretnych figur baletowych (rozdz. Des figures du ballet), sporządzania kostiumów (rozdz. Des habits). I tak autor z zachwytem pisze na przykład o kostiumie tancerza uosabiającego „Wszechświat”. Na głowie miał on Olimp, całe ciało ozdabiała mapa - na nogach umieszczono Włochy, na brzuchu Niemcy, a na sercu Francję. Jezuicki twórca był bardzo wymagający odnośnie samej oprawy scenicznej. Jeżeli temat baletu łączył się z symbolicznym ukazaniem potęgi pieniądza — sugeruje, że należy pokazać wszystkie monety krajowe, potem zagraniczne i to z obu stron. Postulował także różnorodność kostiumów, które miały przede wszystkim olśniewać i zaskakiwać widzów .

\footnotetext{
${ }^{4} \mathrm{~W}$ Encyklopedii wiedzy o jezuitach na ziemiach polski i Litwy, 1564-1995 pod hasłem Szkolnictwo odnaleźć możemy informację, że w Pułtusku prowadzono lekcje gimnastyki. Encyklopedia wiedzy o jezuitach na ziemiach Polski i Litwy 1564-1995, oprac. L. Grzebień SJ, Kraków 1996, s. 661. Także Bronisław Natoński SJ podaje, że w 1585 roku w katalogu kolegium pułtuskiego figuruje praefectus exercitii corporalis (prefekt gimnastyki).

${ }^{5}$ Por. także A. Reglińska-Jemioł, Prowincja tańczy. O edukacji tanecznej w prowincjonalnych szkotach w XVIII wieku (Próba opisu zjawiska na przykładzie szkót jezuickich), [w:] Między barokiem a oświeceniem. Staropolski regionalizm, red. S. Achremczyk, Olsztyn 2008, „Rozprawy i Materiały Ośrodka Badań Naukowych im. Wojciecha Kętrzyńskiego w Olsztynie” nr 241, s. 331-334.

${ }^{6}$ Por. A. Baron, Lettres à Sophie sur la danse, suivies d'entretiens sur les danses ancienne, moderne, religieuse, civile et théâtrale, Paryż 1825; A. Czerwiński, Geschichte der Tanzkunst bei den cultivirten Völkern von den ersten Anfängen bis auf die gegenwärtige Zeit, Lipsk 1862.

7 C.F. Ménestrier, Des Ballets anciens et modernes selon les règles du théatre, Paryż 1682, s. 253. Ménestrier opierał się, choć z pewnymi zastrzeżeniami na francuskim wydaniu Ikonologii Cesarego Ripy (Paryż
} 
Spośród 10 francuskich książek z historii i teorii tańca z tego okresu aż 7 było autorstwa duchownych. Pięć spośród tych prac było autorstwa jezuitów ${ }^{8}$ C. F. Ménestrier, Remarques pour la conduite des ballets, [w:] L'Autel de Lyon (1658), Des Représentations en musique (1681), wspomniana powyżej publikacja Des Ballets anciens et modernes selon les règles du théâtre (1682) oraz dzieło Gabriela Le Jaya, De choreis dramaticis, [w:] Bibliotheca rhetorum (1725) czy Charles'a Poréego, Discours sur les spectacles (1733).

Recenzje pozostałych książek poświęconych sztuce tańca pojawiały się we wpływowym jezuickim czasopiśmie „Les Memoires de Trévoux”. Tu także omówiono nowatorską Sztukę teatru Antoine Françoisa Riccoboniego9.

Należy podkreślić, że na długo przed nastaniem mody na balet w Paryżu, jezuici tworzyli spektakularne widowiska publiczne, a także przedstawienia w obrębie kolegiów. Niektórzy z członków zakonu służyli arystokratom jako mistrzowie ceremonii, a doświadczenia swe przenosili na deski scen szkolnych. I tak na przykład swoją karierę Ménestrier rozpoczął jako organizator fêtes, turniejów i przedstawień teatralnych na dworze księcia de Savoy. Jest także autorem pracy Traité des tournois, joustes, carrousels et autres spectacles publics $(1669)^{10}$.

Kolejne rozdziały tej pracy dostarczają wiele fascynujących szczegółów na temat tych dworskich widowisk. I tak obok podstawowych informacji o Du sujet des Carrousels czy De l'origine des Carrousels, możemy przeczytać o zwierzętach przydatnych w tego typu przedsięwzięciach (autor poświęca temu zagadnieniu rozdział - Des Chevaux, \& des autres Animaux, qui peuvent servir aux Carrousels), dalej o "paramilitarnych" rozgrywkach organizowanych ku uciesze dworu ${ }^{11}$.

W słowniku (Le Grand Dictionnaire Royal) autorstwa francuskiego jezuity Françoisa Pomey z 1740 roku odnajdujemy skromną definicję baletu („balet — tańczyć”), czy nieco bardziej rozbudowaną tańca („taniec - czynność tańczenia; poważny taniec; groteskowy taniec; taniec zwany branle...; tańczyć do muzyki skrzypiec; tańczyć na linie; tancerz; tancerka; mistrz tańca") ${ }^{12}$. Hasła te jednak zdecydowanie poświadcza-

1636-1637). O ile Ripa przedstawia alegorie w klasycznych draperiach, większość baletowych postaci Ménestriera nosi jednak stroje odpowiadające ówczesnej modzie.

${ }^{8}$ Por. J. Rock, Terpsichore at Louis-Le-Grand. Baroque Dance on the Jesuit Stage in Paris, Saint Louis 1996, „Original Studies Composed in English”, nr 13, s. 17-19.

${ }^{9}$ Poczytność i ranga „Les Memoires de Trévoux” zmusily zapewne aktora i teoretyka teatru Riccoboniego do odpowiedzi na stawiane mu w tym piśmie zarzuty. Jak podaje M. Dębowski, było to pismo wspierane przez małżonkę królewską i otoczenie zwalczające Madame de Pompadour. Wiadomo, że Riccoboni wywodził się z tych kręgów - stąd też może atak na jego osobę. M. Dębowski, Wstęp, [w:] A.F. Riccoboni, Sztuka teatru, przekł. i oprac. M. Dębowski, Gdańsk 2005, „Theatroteka. Źródła i Materiały do Historii Teatru", red. D. Ratajczakowa, t. 3, s. 21-23.

${ }^{10}$ Więcej na ten temat: H. Watanabe-O'Kelly, The early modern festival book function and form, [w:] Europa Triumphans: Court And Civic Festivals In Early Modern Europe, red. J.R. Mulryne, H. WatanabeO'Kelly, Ashgate Publishing 2004, „Publications of the Modern Humanities Research Association”.

${ }^{11}$ To niezwykle barwne dzieło przybliża głównie carrousels, ale także inne (pełne efektów specjalnych, fajerwerków, muzyki, tańca, przemówień) widowiska dworskie. Por.: C.F. Ménestrier, Traité des tournois, joustes, carrousels et autres spectacles publics, Lyon 1669.

${ }^{12}$ F. Pomey SJ, Le Grand Dictionnaire Royal, Cologne 1740, s. 34, 67. 
ją utrwaloną już w tych kręgach obecność tańca na scenie. Sam termin balet jezuicki wprowadził w piśmiennictwie europejskim oświeceniowy encyklopedysta Louis de Cahusac (podkreślając, że „prace Ménestriera są podstawowym źródłem wiedzy o balecie szkolnym i pozostaje on największym znawcą tej dziedziny w Europie") ${ }^{13}$.

Balet szkolny, który kulturowo był reakcją na entuzjazm sfer wyższych wobec sztuki tańca, we Francji XVII stulecia odnosił wielkie sukcesy. Jean Loret, siedemnastowieczny kronikarz Paryża, pisał:

W zeszłym miesiącu poszedłem do jezuitów na ich sztukę. Była to tragedia w żywym stylu, wprawiająca publiczność w radosny nastrój. Były tam przyjemne baletowe interludia. Temat wzięty był z Biblii... $\mathrm{Na}$ wejście balet był tak dobrze zatańczony, że można się pokusić o stwierdzenie — jeden z najlepiej zatańczonych we Francji ${ }^{14}$.

Najbardziej prężnym ośrodkiem tanecznym był teatr kolegium Louis-le-Grand. A jego rola w dziejach szkolnego teatru francuskiego jest porównywalna do tej, którą odegrała Comédie-Française w teatrze świeckim ${ }^{15}$.

W szkołach jezuickich libretto było tworzone przez profesora poetyki we współpracy z nauczycielem tańca i muzyki. W libretcie autorzy odwołując się do historii, mitologii i literatury, przedstawiali charakterystyczne cechy młodzieży, skutki jej pragnień i marzeń, zdolność do poświęceń, a wszystko miało być wzorem i przykładem dla młodej publiczności. Znalazło tu też odzwierciedlenie życie polityczne i religijne. Odnaleźć w nim można dyskutowane we Francji teorie, które autorzy librett aprobowali, bądź negowali, ale co ważne, brali czynny udział w życiu intelektualnym epoki.

Najbardziej znaczące jezuickie traktaty teoretyczne poruszające kwestie tańca to wymienione wcześniej Ballets anciens et modernes Menestriera SJ, De ratione discendi et docendi Josepha de Jouvanacy'ego SJ z 1691 roku ${ }^{16}$ oraz De choreis dramaticis (1725) autorstwa Le Jaya SJ ${ }^{17}$. Zdaniem Ireny Kadulskiej, Iuventius, pracujący nad swoją pracą De ratione discendi et docendi $\mathrm{w}$ Collège Louis-le-Grand, potwierdza niejako dominację Francuzów w nauce wiedzy o poezji, ale także w teoretycznej wiedzy o sztuce tańca ${ }^{18}$.

Jouvancy znalazł miejsce na taniec, pieśni i pantomimę między aktami sztuki „aby dać wytchnienie widzom”. Pisał także wprost:

\footnotetext{
${ }^{13}$ Hasło ballet, [w:] Encyclopédie, ou Dictionnaire Raisonné des Sciences, des Arts et des Métiers, Paryż 1765, t. 2, s. 46. (L. de Cahusac jest także autorem monograficznego opracowania o tańcu La danse ancienne et moderne, Paryż 1754).

${ }^{14}$ Cyt. za: J. Rock, dz. cyt., s. 10.

${ }^{15}$ Por.: E. Boysse, Le Théâtre des Jésuites, Paryż 1880, s. 19-21.

${ }^{16}$ Do grona teoretyków, którym bliska była sztuka tańca, należy również zaliczyć francuskiego jezuitę Pierre’a Mambrun (1600-1661), poetę łacińskiego, profesora retoryki i teologii w kolegium w Caen. Wśród jego prac teoretycznych można wymienić: Disseratio poetica de epico carmine, 1652.

${ }^{17}$ Więcej o sylwetce autora por.: Bibliothèque de la Compagnie de Jésus, red. A. Backer, C. Sommervogel, t. 3, Bruxelles-Paris 1890-1932, s. 765-782.

${ }^{18}$ I. Kadulska, Komedia w polskim teatrze jezuickim XVIII wieku, Wrocław 1993, s. 49. Jak zauważają historycy teatru, publikacja Iuventiusa była próbą odejścia od praktyk barokowej sceny jezuickiej, zarazem próbą zaszczepienia na jej grunt tendencji racjonalistycznych. Po raz pierwszy wydano De ratione docendi et discendi Juventiusa w 1703 roku. Podręcznik ten był w Polsce dobrze znany i popularny, najlepiej dostępny jest przedruk lubelski z 1746 roku.
} 
[...] taniec jest rozrywką godną człowieka wysoko urodzonego i dobrze wychowanego, a także użytecznym ćwiczeniem dla młodzieży. A balet jest jak niema poezja, wyraża uczucia poety w kunsztownych ruchach ciała.

Dając wskazówki odnośnie postawy mówcy („wymaga postawy wyprostowanej; głowa żeby nie była pochylona; rękę żeby skromnie układać na piersi; środkowe zaś palce powinny być przystojnie złączone; dalej zwracać należy uwagę na ustawienie nóg: gdy się przemawia, nie mogą one być w ruchu”), wskazuje na naukę tańca, która ma prowadzić do nabrania ogólnej ogłady przez uczniów ${ }^{19}$.

Jouvancy sytuuje balet jedynie u boku tragedii, podkreśla, że ma niejako stanowić rozwinięcie motywów czy tematów sztuki, ma przyciągnąć uwagę widzów (zabawić ich śpiewem, pantomimą i tańcem). I tak jeżeli w tragedii ukazuje się tryumf chrześcijańskiego bohatera - balet winien rozwijać motyw zwycięstwa wiary katolickiej. Jednak teoretyk nie wskazywał na motywy niezależne od treści czy tematu przewodniego tragedii, jak na przykład cztery pory roku, czy cztery etapy życia człowieka.

W tej kwestii idzie dalej G. Le Jay (De choreis dramaticis,). Podkreśla bowiem, że balet nie podlega surowym prawom tragedii i komedii, a jego jedyną zasadą jest to, że wszystkie jego części muszą podlegać ogólnej idei, odpowiadającej intencji autora dzieła. Podaje także, że autor baletu może temat zaczerpnąć z historii, baśni czy stworzyć go sam — stąd rodzą się trzy rodzaje baletu: historyczny, fantastyczny, balet imaginacyjny. Dodaje także czwartą kategorię, która jest swoistym połączeniem trzech poprzednich. (Rozważa także historyczne podłoże tańca, ukazując tradycje greckie czy rzymskie) ${ }^{20}$.

$\mathrm{Z}$ reguły jezuici piszący o tańcu nie zagłębiali się w szczegóły techniczne, choć można znaleźć w ich pracach ślady fachowego słownictwa z zakresu tańca barokowego czy wskazówki dla tancerzy. I tak G. Le Jay pisze w De choreis dramaticis, że gesty i ruchy im bardziej są naturalne, tym większą przyjemność sprawiają oglądającym. I tak, tańcząc wiatr, należy wybrać ruchy lekkie, „głową naprzód”, z częstym wirowaniem. Kreujący w tańcu smutek, będzie przesuwać się wolnymi krokami, czasami wznosząc głowę i dłonie do nieba. Szczęście powinno wyrażać się w szybkich i zwinnych ruchach, przeplatanych podskokami. Tancerze odgrywający ludzi z gminu uderzają o podłogę w sposób ciężki, a ruchy ich powinny być ociężałe. „Dziwne” ruchy rezerwuje dla odgrywających rolę pijanych czy szalonych, dodając, że powstrzymuje się od dalszych komentarzy w tej kwestii, gdyż przynależą one bardziej instruktorowi tańca niż poecie ${ }^{21}$.

Znakomitym współpracownikiem Le Jaya okazał się Charles Porée SJ. Był on także nauczycielem retoryki i poetyki w Collège Louis-le-Grand, a w nim filarem teatru

\footnotetext{
${ }^{19} \mathrm{~J}$. Okoń, O aktorach i sztuce aktorskiej $w$ staropolskim teatrze szkolnym jezuitów, [w:] Aktor w świecie i teatrze, Poznań 1998, „Poznańskie Studia Polonistyczne. Seria Literacka”, t. 5, s. 61-65.

${ }^{20}$ E. Boysse, $d z$. cyt., s. 36-39.

${ }^{21}$ G. Le Jay, De choreis dramaticis, s. 822. Fragmenty niepublikowanego tłumaczenia pióra Johna Rundina na język angielski autorka otrzymała od prof. Judith Rock. Por. także A. Reglińska-Jemioł, Szlakami szkolnej Terpsychory - z badań nad rola i miejscem tańca w staropolskim teatrze szkolnym, [w:] Skoro i tak gram... Edukacja kulturowa poprzez teatr. Materiaty konferencji zorganizowanej przez Instytut Filologii Polskiej UG w dniach 15-16 I 2009 roku, red. G. Tomaszewska, D. Szczukowski, Gdańsk 2009, s. 26-28.
} 
szkolnego i poczytnym autorem ${ }^{22}$. Swym poglądom na temat teatru Charles Poreé dał wyraz w przedmowie do baletu L'Homme instruit par les spectacles, ou le théatre changé en école de vertu (1726). (Podobnie jak w słynnej Mowie o teatrze z 1733 roku, także tu centralnym punktem było pytanie o moralną wartość teatru).

I tak, z 1730 roku pochodzi balet Le Ridicule des Hommes donné en spectacle, propagujący sztukę teatru jako tę, która przez ukazywanie ułomności ludzkich w łagodny i przyjemny sposób zachęca nas do ich poprawy. Pod wpływem ataków jansenistów stworzył balet L'Histoire de la danse (1732), który był swoistą afirmacją moralnej wartości tańca. Podobny wydźwięk miał balet Les Tableaux allégoriques de la vie humaine z 1734 roku. Wiele zresztą produkcji baletowych w latach 1715-1762 dotykało tej tematyki. Często też nazywano je baletami moralnymi. Dwa najpopularniejsze motywy to: krytyka postaw społecznych, a także wartość i wkład sztuki w niesieniu prawd moralnych ${ }^{23}$.

Poreé apelował o traktowanie nauki sztuki tańca nie tylko jako samej rozrywki, ale środka kształtowania oblicza i ducha francuskiego oraz narzędzia formowania charakteru młodzieży. We francuskim stylu tańca upatrywał bowiem „krok lekki, bez porywczości, radosny, ale bez przesadnej łagodności, ułożony i szlachetny" ${ }^{34}$.

W Polsce zainteresowanie baletem szkolnym nie było, oczywiście, tak duże jak we Francji, ale już Łukasz Ligocki wskazywał, że do różnych typów dramatu należy także i ten. Spisane w poznańskim kolegium dzieło tego autora - Compendium humaniorom litterarum z 1691 roku określa jeden z „typów dramatu” jako typ włoski (italicus), per musicam vel cantum affectus explicans cum actione aliqua (,,wyrażający uczucia przez muzykę czy śpiew, w połączeniu z pewną akcją"), a także sermonem aliquem [...] explicans simul per cantum et actionem ${ }^{25}$. Jezuicki teoretyk zaliczył także na przykład salty do partes maiores, tworzących obok aktów scen, występów chóru i intermediów dramat właściwy. Określił ponadto miejsce saltu w strukturze dramatu i spektaklu, podając jednocześnie rodzaje tematyczne tańców. W nawiązaniu do wielkich teoretyków francuskich, którzy w swych podręcznikach poetyki definiowali pojęcie tańca i wskazywali rozwiązania inscenizacyjne, sformułował on także dla potrzeb szkolnego teatru samą definicję:

\footnotetext{
${ }^{22}$ St. Pigoń, $Z$ dziejów dawnego teatru szkolnego, „Pamiętnik Literacki” 1952, z. 1-2, s. 291. Gdy mówimy o znaczeniu wypowiedzi Ch. Poreégo, to istotne jest to, że jego balety były wystawiane także w Polsce, traktat teoretyczny został również w Polsce wydany oraz był w powszechnym użyciu w szkołach. Część traktatu przetłumaczono na język polski i wydano w zbiorze mów. Oznacza to wspólnotę poglądów jezuitów polskich i francuskich.

${ }^{23}$ Kontynuacją owej apologii sztuki są inne balety — La Poésie (1742); Les Merveilles de l'Art (1744); Le Pouvoir de la fable (1752); Les Spectacles du Parnasse (1754). J. Rock, dz. cyt., s. 159.

${ }^{24}$ Więcej: R. Le Béque, Les Ballets des jésuites, „Revue des Cours et Conferences” Paris 1936, nr 10, s. 135.

${ }^{25} \mathrm{~W}$ przeglądzie poetyk szkół jezuickich dokonanym przez Irenę Kadulską możemy odnaleźć informacje na temat komponentów dramatu, jakimi są taniec i muzyka. I tak, autorka podaje, że Jacob Pontanus (autor Poeticarum institutionum libri tres z 1594 roku) wśród części jakościowych komedii wymienia obok fabuły, sposobu wypowiadania się i działania bohaterów, urządzenia sceny, także element muzyczny. I. Kadulska, dz. cyt., 28.
} 
Saltus post choros et intra scena actuum, framearum ensium, hastarum, laurearum, desperatorum, satyrorum, funambulorum, saltus symbolicus mortis, temporis, vitrorum, etc. ${ }^{26}$

Maciej Kazimierz Sarbiewski, autor wysoko cenionej poetyki (1626-1627), przy omawianiu gry scenicznej i dykcji podaje: „[...] dawać wskazówki w odniesieniu do tańca wcale nam nie przystoi i na żart by zakrawało" ${ }^{27}$. (Uznanie za podstawę tragedii „Czynności”, nie zaś „narracji” w poetyce Sarbiewskiego zgodna jest z definicjami właśnie teoretyków baroku i odpowiada barokowej dynamice, wyrażającej się poprzez wprowadzoną na scenę akcję, działanie) $)^{28}$.

Alessandro Donati w swej Ars poetica z 1631 roku uznaje muzykę i taniec za równoprawne ze słowem środki scenicznego wyrazu („Tragoedia est imitatio dramatica actionis illustrium personarum perfectae ac magnae separatim adhibens metrum, harmoniam, saltationem [...]") ${ }^{29}$. Podobnie jest w późniejszej Palaestra eloquentiae ligatae Jacoba Masena z 1657 roku.

Jan Okoń podaje także, że już w 1648 roku można odnaleźć wskazówki w poetykach szkolnych, umożliwiające wprowadzanie w epilogu, czy prologu tańca, a nawet baletów. („Młodzieńcy deklamują, stojąc w miejscu lub poruszając się w koło” ${ }^{30}$ ). Badacz wskazuje ponadto na siedemnastowieczną poetykę z Wilna Poetica practica anno 1648, w której uwaga autora skupiła się na układzie o charakterze baletowym:

[...] przepiękne wrażenie wywołują sceny bez słów, zrealizowane przy pomocy jedynie gestów, zwłaszcza w wypadku wyrażania afektów, przedstawiania spisków [...]. Scenom takim towarzyszyć mogą dźwięki muzyki, co wzbudza zadowolenie ${ }^{31}$.

Odwołuje się do tego tekstu także Andrzej Kruczyński. Podkreśla on, że w Poetyce wyraźnie widać już próbę zarysowania, tworzenia nie tyle dramatu humanistycznego,

\footnotetext{
${ }^{26}$ „Salty po chórach i w środku aktu, włóczniowe, mieczowe, kopijne, laurowe, desperackie, satyrowe, linoskoczków, salty symboliczne, śmierci, czasu, szkleniczne, etc." Ł. Ligocki, Compendium humaniorom literarum scilicet artis grammaticae poeticae ac rhetoricae (1691) (rozdział „Partes dramatum”). Cyt. za: St. Windakiewicz, Teatr kollegiów jezuickich $w$ dawnej Polsce, „Rozprawy PAU Wydziału Filologicznego”, t. 61: 1922, s. 5-7. Por. także: I. Kadulska, Ze studiów nad dramatem wczesnego Oświecenia (1746-1765), Wrocław 1974, „Rozprawy Literackie”, t. 8, s. 49, 52.

${ }^{27}$ M. K. Sarbiewski, O poezji doskonałej, czyli Wergiliusz i Homer. (De perfecta poesi, sive Vergilius et Homerus), przekł. M. Plezia, oprac. St. Skimina, Wrocław 1954. „Biblioteka Pisarzy Polskich”, seria B, nr 4, s. 235.

${ }^{28}$ Jan Okoń przypuszcza, że uwaga ta jest wyrazem liczenia się z ówczesną włoską praktyką sceniczną, którą Sarbiewski poznawał niemal równocześnie z Władysławem IV. Autor podkreśla, że dla pełnego zrozumienia teorii Sarbiewskiego jest konieczne dostrzeżenie w niej braku pewnych elementów, w tym obecności muzyki i baletu jako środków scenicznego wyrazu. J. Okoń, $Z$ zagadnień baroku w szkolnym dramacie jezuickim w Polsce wieku XVII, [w:] Dramat i teatr. Konferencja teoretycznoliteracka w Świętej Katarzynie, Wrocław 1967, s. 17-18.

${ }^{29}$ I. Kadulska, Komedia w polskim teatrze jezuickim, 30-33. W swej Ars poetica Donati przeciwstawiał się ograniczeniu komedii przez Riccoboniego wyłącznie do naśladowania jakiejś zabawnej przywary, ułomności za pomocą tańca, muzyki i sztuki dramatycznej. A. Donati, Ars poetica, sive Institutionum artis poeticae libri tres, Romae 1631, s. 261 (Antonius Riccobonus immutatis paucis verbis sic definit. Est imitatio; quae fit metro, saltatione, harmonia, modo dramatico in materia eius vitii, quod risum movet).

${ }^{30}$ J. Okoń, Dramat i teatr szkolny. Sceny jezuickie XVII wieku, Wrocław 1970, „Studia Staropolskie”,

t. 26 , s. 236.

${ }^{31}$ Tamże, s. 259-260.
} 
co „tekstu - scenariusza teatralnego”, wzbogaconego i urozmaiconego wszystkimi dostępnymi środkami scenicznego wyrazu, w tym muzyką, pantomimą i tańcem ${ }^{32}$.

Najpełniejszy wyraz poglądów zakonu na reguły gry aktorskiej, jakich powinny przestrzegać sceny szkolne, znajdujemy w Dissertatio de actione scenica ${ }^{33}$ (1727) Franciszka Langa SJ ${ }^{34}$. Pierwsza część dzieła Langa przeznaczona jest dla „choraga” — obok komentarzy na temat akcji scenicznej, znalazły się podstawowe informacje dotyczące gatunków dramatycznych. Dla jezuity bawarskiego na grę aktorską składało się wiele elementów - postawa ciała, ruch, gest, wymowa, mimika. Jako jeden z nielicznych teoretyków teatru, formułując pojęcia tak podstawowe dla scenicznej realizacji przedstawienia, starał się nadać swojej pracy typowo użytkowy charakter. Autor dawał aktorowi szczegółowe wskazówki co do sposobu ustawienia stóp, układu nóg, bioder, ramion, rąk i palców, głowy i mimiki twarzy.

Za największe jego osiągnięcie uważa się potraktowanie gry scenicznej jako sztuki niezależnej, choć uwikłanej w retoryczne powinowactwa. Pozostaje sztuką samodzielną w geście, ruchach ciała, mimice i swych symbolicznych sensach ${ }^{35}$.

Już w momencie założenia Towarzystwa Jezusowego taniec pełnił znaczącą rolę w europejskiej kulturze i stylu życia. A przez następne półtora wieku sztuka tańca, wzbogacona o nowe trendy, umocniła swe miejsce na scenie teatralnej i życiu codziennym (tu najlepszym przykładem jest ballet de cour). Przez ostatnią dekadę wieku XVIII sytuacja zmieniła się raz jeszcze — taniec teatralny stał się technicznie skomplikowany, a amatorzy zupełnie zniknęli ze sceny, która stała się przestrzenią zarezerwowaną dla zawodowców. Arystokracja pozostała przy tańcu towarzyskim.

Balet w szkolnym teatrze Societatis Iesu postrzegany był jako nowy, bardziej efektowny i czytelny sposób moralizowania i nauczania, swoiste narzędzie pedagogiczne i propagandowe. Zanim ostatecznie uzyskał status samodzielnej, dramatycznie

\footnotetext{
${ }^{32}$ A. Kruczyński podkreśla, że chór wykonywał ewolucje taneczne na proscenium, gdzie malowano specjalne pola ułatwiające chórzystom poruszanie się w ramach ściśle zaprogramowanej choreografii. A. Kruczyński, W teatrach jezuickich, [w:] J. Lewański, Dramat i teatr średniowiecza i renesansu w Polsce, Warszawa 1981, „Dzieje Teatru Polskiego”, t. 1, s. 414; 464.

${ }^{33}$ Pełny tytuł tego dzieła: Dissertatio de actione scenica, cum figuris explicantibus et observationibus quibusdam de arte scenica. Auctore P. Francisco Lang Societatis Iesu. Accesserunt imagines symbolicae pro exhibitione et vestitu theatrali, Monachium 1727.

${ }^{34}$ Jak podaje J. Golińska, „Lang zaczął pisać swe dzieło prawdopodobnie około 1720 roku. Siedem tygodni po jego śmierci, w listopadzie 1725 roku, pierwszy cenzor jezuicki otrzymał ukończoną książkę do zaopiniowania. Wydano ją raz jeden w bardzo małym nakładzie dopiero w dwa lata później. Nigdy ponadto nie osiągnęła zamierzonego przez autora celu — nie stała się podręcznikiem... Dopiero w 1889 roku Karl von Reihnardstötter wymienił dzieło Langa w swoim studium na temat monachijskiego dramatu jezuickiego. Od tamtej pory zaczęto omawiać i komentować „Disseratio”, jednak — jak podkreślają współcześni niemieccy badacze — nierzadko błędnie, zapewne głównie z powodu niełatwej, późnobarokowej łaciny oryginału i utrudnionego dostępu do egzemplarzy książki, których zachowało się jedynie kilka”. J. Golińska, Wstęp, [w:] F. Lang SJ, Rozprawa o sztuce scenicznej, przekł. J. Golińska, „Dialog” 2001, nr 8, s. 168. Por. także I. Kadulska, Nota edytorska, [w:] F. Lang, Sylwetki symboliczne przysposobione do teatralnych strojów $i$ występów [Imagines symbolicae adaptatae exhibitioni et vestitui theatrali], do druku podała I. Kadulska, przekł. M. Szlachcikowska, [w:] Aktor w świecie i teatrze..., s. 188-189.

${ }^{35}$ Por. J. Lipiński, Planeta Luna. Wstęp do historii sztuki aktorskiej w Polsce, „Pamiętnik Teatralny” 1971, z. 2.
} 
ukształtowanej sztuki przekazującej treści i emocje, skoki i salty na scenie służyły przede wszystkim widowiskowości i uatrakcyjnieniu przedstawień, stanowiąc jedynie jego części. Twórcy szkolnych spektakli w kształtowaniu nowego wzorca osobowego starali się wykorzystywać wszelkie dostępne im środki teatralne - tekst dramatu, możliwości sceniczne aktora, światło, scenografię, czy wreszcie muzykę i taniec ${ }^{36}$.

Odrębną problematyką wydaje się gatunkowa i tematyczna różnorodność szkolnych form tanecznych, sposób ich zapisu i współczesne możliwości odczytań. Przykłady notacji tańca polskiej sceny jezuickiej nie przetrwały do naszych czasów. I trudno jednoznacznie stwierdzić, czy w ogóle w Polsce posługiwano się sztuką chorégraphie. Do wniosku, że zapis ruchu scenicznego nie był jezuitom obcy, skłania między innymi fakt bliskiej współpracy jezuitów francuskich z współtwórcą pisma tanecznego Pierrem (czasami nazywany Charles-Louis) Beauchamps'em, dalej komentarze na łamach jezuickiej prasy (Les Memoires de Trévoux) dotyczące systemu notacji Raula Augera Feuilleta, i wreszcie wykorzystywanie podobnych układów choreograficznych, czy tanecznych entrées w różnych ośrodkach europejskich.

Programy teatru jezuickiego opracowane pieczołowicie przez zespół Władysława Korotaja w tomie Dramat staropolski od początków do powstania sceny narodowej. Bibliografia ${ }^{37}$ potwierdzają przykłady 427 wstawek choreograficznych. Pamiętać warto o swoistej słabości szlachty do walorów widowiskowych i czysto plastycznych, jakie przynosiły stosowne dekoracje, efekty teatralne, antykizujące kostiumy, żywe obrazy, a zapewne także tańce ${ }^{38}$.

W tradycji szkolnych przedstawień teatru jezuickiego trudno wyznaczyć wyraźne granice pomiędzy trzema formami ruchu scenicznego: skokiem, saltem czy tańcem i wskazać zakres najbardziej reprezentatywnego słownictwa stosowanego do opisania wymienionych form. Programy szkolnych przedstawień dostarczają przykładów, gdzie wszystkie trzy pojęcia występują razem w jednej sztuce — Splendor Sapiehanae Sagittae Casimiro... (1686), w której „Wystawiano »skok żołnierski« obok »saltu« i »tańca anagramatycznego"".

W drukowanych programach teatralnych rzadko podawano wskazówki dotyczące wykonania układów choreograficznych. Istotne jest pytanie: co zatem wnosi lektura programów teatru jezuickiego do wiedzy o tańcu na scenie szkolnego teatru? Przede wszystkim programy teatralne były istotnym źródłem poznania życia teatralnego, faktem teatrologicznym, często odbiciem przedstawienia. $Z$ jednej bowiem strony informowały o sztuce, treści i przebiegu zdarzeń, jak i przekazywały wiadomości o spektaklu, w tym także o wprowadzaniu form tanecznych ${ }^{39}$.

\footnotetext{
${ }^{36}$ Zob. I. Kadulska, Problemy teatru jezuickiego połowy XVIII wieku, „Zeszyty Naukowe Wydziału Humanistycznego Uniwersytetu Gdańskiego. Prace Historyczno-Literackie" 1972, nr 1.

${ }^{37}$ Dramat staropolski od początków do powstania sceny narodowej. Bibliografia, t. 2: Programy drukiem wydane do roku 1765, cz. 1: Programy teatru jezuickiego, oprac. zespół pod kierunkiem W. Korotaja, Wrocław 1976, „Książka w Dawnej Kulturze Polskiej”, t. 14.

${ }^{38}$ Ogólny, statystyczny obraz klasyfikacji tematów realizowanych we wstawkach choreograficznych różnego typu por. A. Reglińska-Jemioł, Prowincja tańczy..., s. 335-345,

39 Tamże, s. XIX-XX.
} 
Szkolny teatr efektów nie ujawnia dziś wszystkich swoich barw i możliwości. Ubóstwo szczegółów informacji o tańcach w zapisanych tekstach dramatycznych i programach spektakli sprawia wrażenie, że najwyżej ceniono funkcję widowiskową saltów (osadzoną w przestrzeni sceny i związaną ściśle z teatralną konkretyzacja). Poza przestrzenią sceny (w druku na przykład sumariusza) nie widziano potrzeby umieszczania dokładniejszych opisów tańca. Funkcja dramaturgiczna, związana z akcją była słabiej uwyraźniana i wykorzystywana w strukturze dramatycznej tekstów ${ }^{40}$.

W toku podjętych badań nad miejscem tańca w teatrze szkolnym z repertuaru sceny jezuickiej wyraźnie wyodrębnia się grupa przedstawień, których programy odnotowują formy baletowe (15 tytułów). Balet jezuicki pozostawał bliski oświeceniowym tendencjom reformatorskim $\mathrm{w}$ dziedzinie tańca. W tym miejscu należy krótko przypomnieć dzieło wielkiego reformatora baletu - Jeana Georges'a Noverre'a (1727-1810). Swój program odnowy sztuki baletowej zawarł w Lettres sur la dance et sur les ballets (1760). Jako podstawę reformy Noverre’a badacze podają poszukiwanie nowego wyrazu tańca - wyrażającego myśli, emocje, takiego, w którym łączyłyby się wysiłki muzyka, poety i choreografa. Jemu to właśnie ostatecznie udało się stworzyć nową formę widowiska zwaną ballet d'action - baletu z akcją, a w nim zrealizować swe tezy o tańcu (oderwanie baletu od opery; budowanie widowiska baletowego według powszechnie obowiązujących $w$ teatrze zasad dramaturgicznych; traktowanie techniki tańca nie jako celu, lecz jako środka do wyrażenia jakiejś idei; wciągnięcie w akcję dramatyczną corps de ballet, harmonijne funkcjonowanie poszczególnych elementów baletu — tańca, pantomimy, muzyki i scenografii) ${ }^{41}$.

Z połowy XVIII wieku zachowały się cztery drukowane programy baletów z akcją (dwa $\mathrm{z}$ nich wydane we współczesnej antologii dramatu jezuickiego ${ }^{42}$ ): Balet mężnego człowieka w osobie Herkulesa wyrażająy, Wilno 175...?; Balet bożka trunków Bachusa wesoly początek, smutny zaś koniec majacy, Wilno 1754; Balet w osobie Oresta, kare bogów na ludzi sprowadzona za nieuszanowanie świątnic i oraz pewna obronę $w$ niebezpieczeństwie życia garnacym się do nich wyrażajacy, Wilno 1754 oraz Balet, wiek ludzki w czterech częściach zamknięty, wiosna mtody, latem śrzedni, jesienia podeszty, zima sędziwy wiek wyrażajacy, Wilno 1761. Już same tytuły programów wskazują na charakter baletowego spektaklu i tematykę utworów, podkreślając znaczenie baletu jako nowego źródła moralnych pouczeń i formy przekazywania treści edukacyjnych.

Rozwijająca się stopniowo myśl teoretyczna o tańcu znalazła wyraźne odbicie w piśmiennictwie jezuickim XVII i XVIII wieku. Wypowiedzi te niewątpliwie były reakcją na rosnąca popularność tej sztuki scenicznego wyrazu, mnożących się przedstawień baletowych i koniecznością unormowania zasad obecności tańca w strukturach szkoły

\footnotetext{
${ }^{40}$ Więcej: I. Kadulska, Ze studiów nad dramatem jezuickim wczesnego Oświecenia (1746-1765), Wrocław 1974, „Rozprawy Literackie”, nr 8, 59-60.

${ }^{41}$ Postulaty Noverre’a formułuje między innymi w swej książce Janina Pudełek, $Z$ historii baletu, Warszawa 1981, s. 16.

${ }^{42}$ Teatr jezuicki XVIII i XIX wieku w Polsce. $Z$ antologia dramatu, wstęp i oprac. I. Kadulska, Gdańsk 1997.
} 
i przestrzeni teatru. Zasadnicze tezy tejże estetyki możemy odnaleźć w pismach francuskich jezuitów. Tu sztuka baletowa rozwinęła się najpełniej (wskazuje się na wpływ sceny paryskiej — kolegium Louis-le-Grand, wyraźnie podkreślając „utylitarny” charakter szkolnych inscenizacji baletowych, które miały służyć przede wszystkim rozpowszechnianiu jezuickiej myśli religijnej) ${ }^{43}$. Choć jezuicka myśl o tańcu nie wywarła istotnego wpływu na teorie dramatyczne polskiego oświecenia, potwierdzała europejską przynależność naszej kultury i świadczyła o ciągłości refleksji estetycznej środowiska członków Towarzystwa Jezusowego.

\section{Reminiscences of the Art of Dance in Jesuit Literature}

\section{Summary}

The achievements of a school dance seem original and valuable. It was said that: There is no one like the Jesuits for doing pirouettes. Also in France three of the ballet masters - Beauchamps, Pécour, and Dupré - worked for the Jesuits and were directors of the Royal Academy, which became later the Paris Opéra.

The art of dancing, and in particular ballet, is a field, thanks to which, the distinct and unique nature of the Jesuit college theatre can be depicted against the background of the theatrical map of the 18th century. Terpsichore did not solely serve the purposes of entertainment, but was perceived as a perfect tool in the cultivating of higher values (such as science, faith, patriotism, or morality) or in the propagating of a defined model of behaviour. Such an attitude can be observed at all stages of the development of the art of dance - from ceremonial rituals, through choreographic interludes, i.e. somersaults and leaps, and full pantomimes, to completely independent ballets with plot and action. Among their propagators and creators was Gabriel Le Jay, whose treatise Liber de choreis led dance in school theatres onto a new road. In Poland from the middle of the 18th century we have four printed programmes of Jesuit performances of ballets with action. Ballets latter appeared on the boards of school theatres together with the theatrical reform and are undoubtedly a novelty in the repertoire of the middle of the 18th century. Although they are based on Baroque emblematic constructions, there can be noticed in these realisations an attempt to imitate nature and an emphasis on the artistic and imaginative form of the spectacle. These elements constitute important points in Noverre's reform of dance. Surprisingly, when writing about dance we become aware of the overlapping history. The cultural world was changing and this was reflected in the dance or ballets of the day.

\footnotetext{
${ }_{43}$ Por. The Reader's Encyclopedia of World Drama, red. J. Gassner, E. Quinn, Londyn 1975, s. 492; H. Kogler, The Concise Oxford Dictionary of Ballet, Londyn 1977, s. 281.
} 